\title{
GSK-3 $\beta$ mediates the effects of HNF-1 $\beta$ overexpression in ovarian clear cell carcinoma
}

\author{
NAOKI KAWAHARA, AYANO MIZUTANI, SHO MATSUBARA, YOSHINORI TAKEDA and HIROSHI KOBAYASHI
}

Department of Obstetrics and Gynecology, Nara Medical University, Kashihara, Nara 634-8522, Japan

Received October 16, 2019; Accepted February 13, 2020

DOI: $10.3892 / \mathrm{etm} .2020 .9250$

\begin{abstract}
Deubiquitinase USP28 is a target gene of the transcription factor HNF1 homeobox $\beta$ (HNF-1 $\beta$ ), which promotes the survival of ovarian clear cell carcinoma (OCCC) cell lines. However, the pharmacological inhibition of HNF-1 $\beta$ can cause several adverse effects as it is abundantly expressed in numerous organ systems, including the kidney, liver, pancreas and digestive tract. Therefore, small interfering RNA (siRNA) screening was performed in the current study to identify other potential downstream targets of the HNF-1 $\beta$-mediated pathway. The results revealed that glycogen synthase kinase-3 $\beta$ (GSK-3 $\beta$ ) may be a potential downstream target affecting cell viability. To further clarify the effects of GSK-3 $\beta$, two human OCCC cell lines, TOV-21G (HNF-1 $\beta$ overexpressing line) and ES2 (HNF-1 $\beta$ negative) were transfected with siRNA targeting GSK-3 $\beta$ or control vectors. Loss-of-function studies using RNAi-mediated gene silencing indicated that HNF-1 $\beta$ facilitated GSK-3 $\beta$ expression, resulting in the loss of phosphorylated nuclear factor- $\kappa \mathrm{B}(\mathrm{p}-\mathrm{NF} \kappa \mathrm{B})$ and the reduction of TOV-21G cell proliferation. The cell proliferation assay also revealed that GSK-3 $\beta$ inhibitors rescued the effects of HNF-1 $\beta$ silencing on cell viability in a dose-dependent manner. Furthermore, the GSK-3 $\beta$ inhibitor, AR-A014418, effectively inhibited tumor cell proliferation in a xenograft mouse model. In conclusion and to the best of our knowledge, the current study was the first to determine that GSK-3 $\beta$ is a target gene of HNF-1 $\beta$. In addition, the results of the present study revealed the novel HNF-1 $\beta$-GSK-3 $\beta$-p-NFKB pathway, occurring in response to DNA damage. Targeting this pathway may therefore represent a putative, novel, anticancer strategy in patients with OCCC.
\end{abstract}

Correspondence to: Dr Naoki Kawahara, Department of Obstetrics and Gynecology, Nara Medical University, 840 Shijo-cho, Kashihara, Nara 634-8522, Japan

E-mail: naoki35@naramed-u.ac.jp

Key words: ovarian clear cell carcinoma, glycogen synthase kinase-3 $\beta$, hepatocyte nuclear factor- $1 \beta$, nuclear factor- $\kappa \mathrm{B}$

\section{Introduction}

Approximately, 239,000 new cases of ovarian cancer and 152,000 deaths due to this disease were reported worldwide (1). The frequency of clear cell carcinoma (CCC) is thought to be 5\%-10\% of all epithelial ovarian cancers in Western countries, but it is higher $(>20 \%)$ in Japan. Ovarian clear cell carcinoma (OCCC) is resistant to platinum chemotherapy and it is characterized by poor prognosis. Therefore, novel strategy to overcome OCCC is required for a more effective outcome.

The transcription factor HNF1 homeobox $\beta$ (HNF-1 $\beta$ ) is upregulated in endometriosis and OCCC, suggesting that it might be a key molecule in endometriosis-associated CCC (2). We previously reported that HNF-1 $\beta$ promotes $\mathrm{G} 2$ phase cell cycle arrest and survival in human CCC cell lines through up-regulation of the phosphorylation of Chk1 (p-Chk1) protein in response to a genotoxic stress (3). Moreover, we reported that HNF-1 $\beta$ overexpressing cells survive by persistent Chk1 activation, facilitated by USP28-mediated Claspin stabilization (4). Therefore, therapy targeting the HNF-1 $\beta$-USP28-Claspin pathway could be a novel targeted molecular therapy for HNF-1 $\beta$ overexpressing CCC. However, pharmacological inhibition of HNF-1 $\beta$ or Chk1 could cause several adverse effects, because they show comparable abundance in numerous organs such as the kidney, liver, pancreas, and digestive tract. While some study reported potential targets of HNF-1 $\beta(5,6)$, to further investigate the potential role of HNF-1 $\beta$, we conducted small interfering RNA (siRNA) library screening, through which the effects of gene silencing on biological phenotypes can be systematically explored. Our results are expected to provide insights into the molecular mechanisms underlying the HNF-1 $\beta$-mediated cell survival in OCCC.

\section{Materials and methods}

Cell lines. All cells were maintained in humidified incubator at $37^{\circ} \mathrm{C}$ with $5 \% \mathrm{CO}_{2}$. These cells were maintained in Dulbecco's modified Eagle's medium/Ham's F-12 with L-Glutamine and Phenol Red containing 10\% fetal bovine serum and $100 \mathrm{U} / \mathrm{ml}$ penicillin and streptomycin, and used at sub confluent status. TOV-21G and ES2 cell lines were obtained from American Type Culture Collection. Among these CCC lines, TOV-21G shows HNF-1 $\beta$ overexpression, while ES2 is negative for HNF-1 $\beta$ expression. 
siRNA library screening. We carried out siRNA library screening of human cell cycle regulation-related genes (G-003205; Dharmacon). TOV-21G cell line was grown in 6-well plate at a concentration of $4.0 \times 10^{5}$ cells per well and si-HNF-1 $\beta$ (M-007921-01; Dharmacon) or si-control (D-001210-02; Dharmacon) was reverse transfected rapidly at $5 \mathrm{nM}$ according to manufacturer's recommended protocol. At $24 \mathrm{~h}$ after transfection, HNF-1 $\beta$ knockdown and control cells were plated in three wells of 96-well plate, respectively, at a concentration of 5,000 cells per well. In each of the three wells of HNF-1 $\beta$ knockdown and control cells, we transfected $5 \mathrm{nM}$ of siRNAs for screening. After $48 \mathrm{~h}$, we measured cell viability by MTT assay (Cell Proliferation kit I; Roche) according to the recommended protocol. For each 96-well plate, we transfected si-control as negative control, and si-PLK1 (M-003290-01; Dharmacon) as positive control. Candidates were extracted as follows. Firstly, difference in cell viability between TOV-21G (si-control) and TOV-21G (si-HNF-1 $\beta$ ) was considered to be an effect of HNF-1 $\beta$ interference on cells. Secondly, the cell viability of negative control group was verified to show normal distribution, and we corrected the test results based on difference with negative control.

Western blotting. TOV-21G and ES2 cells were grown in 6-well dish ( $4.0 \times 10^{5}$ cells per well) and si-glycogen synthase kinase-3 $\beta$ (si-GSK-3 $\beta$; D-003010-09; Dharmacon) and si-control were reverse transfected at $5 \mathrm{nM}$ according to manufacturer's recommended protocol. TOV-21G cells were grown in 6-well dish $\left(2.0 \times 10^{5}\right.$ cells per well) and si-GSK-3 $\beta$, si-HNF-1 $\beta$ (M-007921-01 or D-009721-02; Dharmacon) and si-control were reverse transfected at 5 or $20 \mathrm{nM}$ according to manufacturer's recommended protocol. Then, we extracted protein at 48 and $72 \mathrm{~h}$ after transfection. Samples were applied to Mini-PROTEAN ${ }^{\circledR}$ TGX $^{\text {TM }}$ Gels $4-15 \%$, and transferred by Trans-Blot ${ }^{\circledR}$ Turbo $^{\text {TM }}$ Transfer Pack (Bio-Rad Laboratories, Inc.). Protein extraction from nuclear and cytoplasma separately were conducted using NE-PER Nuclear and Cytoplasmic Extraction reagents (78833; Thermo Fisher Scientific, Inc.) according to manufacturer's recommended protocol. The following antibodies were used for western blotting: primary antibodies against HNF-1 $\beta$ (ab187744, diluted 1:10,000; Abcam), GSK-3 $\beta$ (\#12456, diluted 1:1,000; Cell Signaling Technology, Inc.), phospho-GSK-3 $\alpha / \beta$ (\#9331, diluted 1:1,000; Cell Signaling Technology, Inc.), NFкB (\#8242, diluted 1:1,000, Cell Signaling Technology, Inc.), phospho-NFкB (\#3033, diluted 1:1,000; Cell Signaling Technology, Inc.), phospho-Chk1 (\#2349, diluted 1:10,000; Cell Signaling Technology, Inc.) and actin (sc-8432, diluted 1:5,000; Santa Cruz Biotechnology, Inc.). Horseradish peroxidase-conjugated secondary antibodies against mouse (sc-2005, 1:10,000; Santa Cruz Biotechnology, Inc.) and rabbit (sc-2004, diluted 1:10,000; Santa Cruz Biotechnology, Inc.) were used.

quantitative polymerase chain reaction ( $q P C R)$. RNA extraction from TOV-21G and ES2 cells were performed at 24 and $48 \mathrm{~h}$ after transfection $(5 \mathrm{nM})$ by Taq Man Gene Expression Cells-to- $\mathrm{CT}^{\text {тм }}$ kit (Invitrogen; Thermo Fisher Scientific, Inc.) according to the manufacturer's protocol. PCR was performed on StepOnePlus ${ }^{\mathrm{TM}}$ Real Time PCR System (Applied Biosystems; Thermo Fisher Scientific, Inc.) with
$4 \mu 1$ of cDNA, $10 \mu 1$ of TaqMan Gene Expression Master Mix (4369016; Applied Biosystems; Thermo Fisher Scientific, Inc.), $1 \mu \mathrm{l}$ of GSK-3 $\beta$ or GAPDH TaqMan Gene Expression Assay (Hs01047719_m1 or Hs99999905_m1; Applied Biosystems; Thermo Fisher Scientific, Inc.) and $5 \mu$ of nuclease-free water

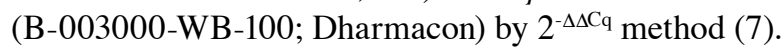

Cell cycle analysis. TOV-21G cells were grown in 6-well dish $\left(2.0 \times 10^{5}\right.$ cells per well) and si-GSK-3 $\beta$ and si-control were reverse transfected at $5 \mathrm{nM}$ according to manufacturer's recommended protocol. Then, the cells were harvested for $48 \mathrm{~h}$ and washed in phosphate-buffered saline (PBS) before fixation in cold $70 \%$ ethanol which were added drop wise to the pellet while vortexing. Cells were fixed for $30 \mathrm{~min}$ at $4^{\circ} \mathrm{C}$. Fixed cells were washed twice in PBS and centrifuged by $3,000 \mathrm{x} \mathrm{g}$ for $5 \mathrm{~min}$. Cells were incubated with $950 \mu \mathrm{l}$ from $10 \mathrm{mg} / \mathrm{ml}$ of a ribonuclease (313-01461; Nippon Gene Co., Ltd) and $50 \mu \mathrm{l}$ from $1 \mathrm{mg} / \mathrm{ml}$ of a propidium iodide (P378; Dojindo Laboratories). A BD FACSCalibur ${ }^{\mathrm{TM}}$ (BD Biosciences) flow cytometer was used to analyze the cell population for cell cycle changes.

Apoptosis assay. TOV-21G cells were seeded into 6-well plates at a concentration of $2.0 \times 10^{5}$ cells per well and the cells were then treated with si-GSK-3 $\beta$ and si-control. Harvest the cells after the incubation period for $48 \mathrm{~h}$ and wash in cold PBS. Re-centrifuge the washed cells, discard the supernatant and resuspend the cells in 1X Annexin-binding buffer (Applied Biosystems; Thermo Fisher Scientific, Inc.). Determine the cell density and dilute in $1 \mathrm{X}$ Annexin-binding buffer to 1.0x $10^{5}$ cells $/ 100 \mu \mathrm{l}$. Add $5 \mu 1$ Alexa Fluor ${ }^{\circledR} 488$ Annexin V (Applied Biosystems; Thermo Fisher Scientific, Inc.) and propidium iodide to adjust its final concentration as $2.5 \mu \mathrm{g} / \mathrm{ml}$. Incubate the cells at room temperature for $15 \mathrm{~min}$. After the incubation period, add $400 \mu \mathrm{l}$ of $1 \mathrm{X}$ Annexin-binding buffer, mix gently and keep the samples on ice. As soon as possible, analyze the stained cells by BD FACSCalibur ${ }^{\mathrm{TM}}$ to assess the percentage changes in early and late apoptosis.

IncuCyte ZOOM ${ }^{T M}$ image capture and analyses for cell growth. Cell proliferation was studied using the IncuCyte ZOOM $^{\mathrm{TM}}$ Live-Cell Imaging system (Essen BioScience) as previously described for kinetic monitoring of proliferation and cytotoxicity of cultured cells (8). IncuCyte image assays quantify how rapidly the proportion of the area covered by cells increases with time as a function of cell proliferation rate (8). TOV-21G cells were seeded into 6-well plates at a concentration of $2.0 \times 10^{5}$ cells per well and all cells were then treated by $42 \mu \mathrm{M}$ bleomycin at $0 \mathrm{~h}$. The AR-A014418 $(20 \mu \mathrm{M})$ or vehicle (dimethyl sulfoxide) group were transferred to the IncuCyte $\mathrm{ZOOM}^{\mathrm{TM}}$ apparatus, and incubations continued over $72 \mathrm{~h}$, with images collected every three hours. All images were analyzed focused on confluence (\%).

In vivo assay. All animal experiments were conducted according to Guidelines for Proper Conduct of Animal Experiments (June 1, 2006; Science Council of Japan). And this study was approved by the animal ethics committee of Nara Medical University (reference no. 12594). To generate murine subcutaneous tumors, $4.5 \times 10^{6} \mathrm{TOV}-21 \mathrm{G}$ cells in 


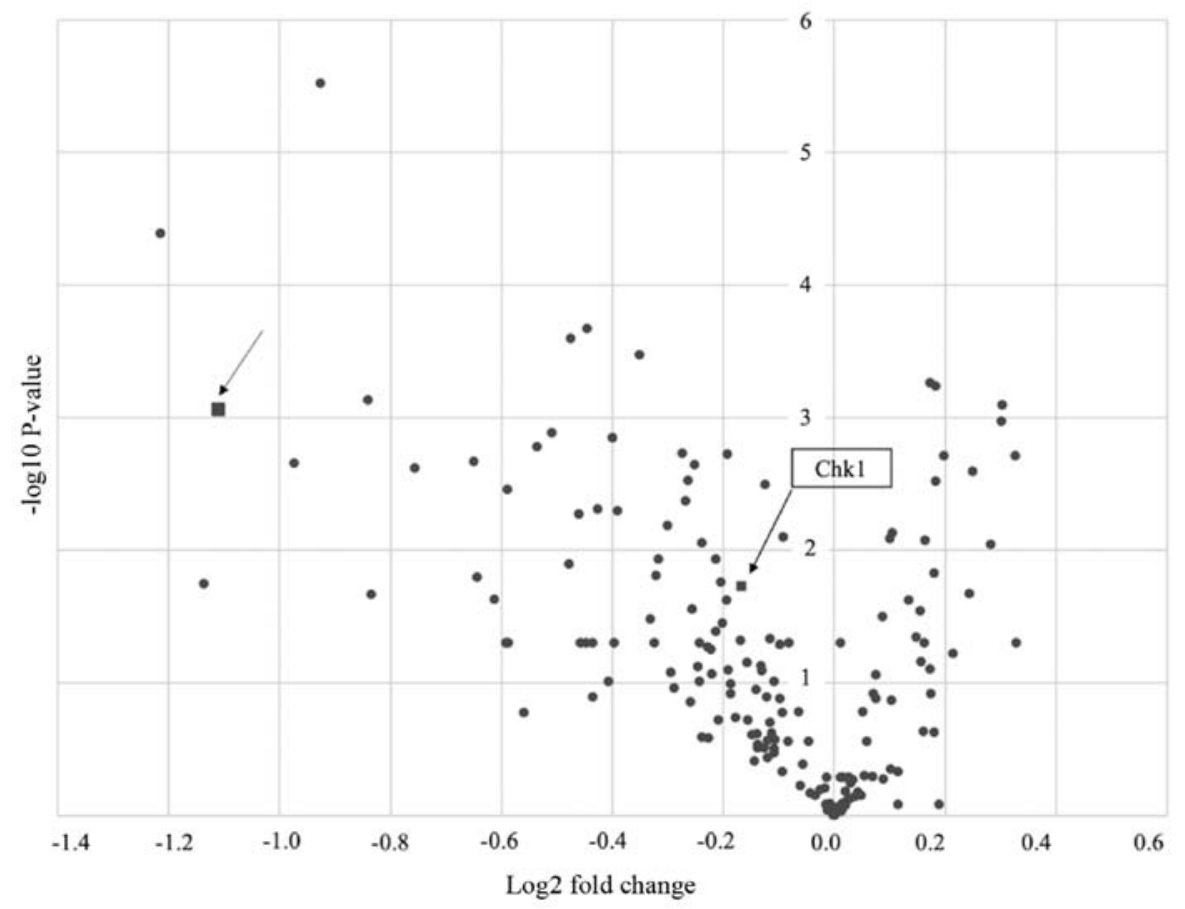

Figure 1. GSK-3 $\beta$ was extracted as the target gene of HNF-1 $\beta$. The TOV-21G cell line (HNF-1 $1 \beta$ overexpression) was utilized in the current study. The volcano plot demonstrates the result of small interfering RNA library screening among 169 cell cycle-associated genes. The x-axis presents cell variability compared with the HNF-1 $\beta$ knockdown group and the $y$-axis presents the P-value. The square and arrow represent the GSK-3 $\beta$ gene. GSK-3 $\beta$, glycogen synthase kinase-3 $\beta$; HNF-1 $\beta$, HNF1 homeobox $\beta$.

$200 \mu 1$ of PBS were injected subcutaneously into the neck of the dorsal midline in 5- to 6-week-old athymic nude mice (SLC) under maintenance of $2 \%$ after $5 \%$ introduction of inhaled isoflurane (Pfizer Inc.). Ten days after the injection, from the point of tumor palpable, we separated the mice into two groups: inhibitor group and control group ( $\mathrm{n}=5$ for each), and intraperitoneally injected AR-A014418 (S7435; Shelleck Chemicals) at a dose of $1 \mathrm{mg} / \mathrm{kg}$ or PBS with the same amount of dimethyl sulfoxide every day for one week. Physical method (cervical dislocation) was applied to conduct sacrifice of the mice.

Statistical analysis. Data were assessed whether they present normal distribution by Shapiro-Wilk analysis. In normal distribution, t-test was applied and presented as mean \pm SD. In case of variables that did not present normal distribution, Mann-Whitney U test were applied and expressed as median \pm SD. Analyses were performed by SPSS version 25.0 (IBM Corp.). All statistical analysis was performed at least twice. Two-sided $\mathrm{P}<0.05$ was considered to indicate a statistically significant difference.

\section{Results}

GSK-3 $\beta$ is a key gene regulating $H N F-1 \beta$ overexpression in $C C C$. The siRNA library screening was conducted by focusing on the cell survival rate among 169 cell cycle-related genes. We prepared HNF-1 $\beta$ knockdown and control cell line using TOV-21G (HNF-1 $\beta$ overexpressing OCCC cell line), and transfected siRNA library to both cell lines. Our hypothesis was as follows: if there would be a candidate gene related to HNF-1 $\beta$ signaling, the wild type cell line (with HNF-1 $\beta$ over- expression) would show low viability. TOV-21G si-control cell line showed significant reduced rate of cell survival compared with TOV-21G si-HNF-1 $\beta$ cells $(46.31 \pm 8.60$ vs. $100.00 \pm 5.82$, $\mathrm{P}=0.001$; Fig. 1). As a result, GSK-3 $\beta$ was extracted as the candidate gene. As each siRNA library consisted of four different sequences, we determined the most effective sequence (5'-GAAGUCAGCUAUACAGACA-3') by MTT assay.

GSK-3 $\beta$ plays important role in growth of HNF-1 $\beta$ overexpressing cells. To determine whether GSK-3 $\beta$ has a selective effect in cell lines with or without HNF-1 $\beta$, we assessed the effect of GSK-3 $\beta$ RNA interference by MTT assay. In TOV-21G (HNF-1 $\beta$ overexpression), si-GSK-3 $\beta$ group showed significantly decreased cell proliferation at 48 and $72 \mathrm{~h}$ to si-control group $(85.47 \pm 7.24$ vs. $101.93 \pm 6.65$, $\mathrm{P}=0.015 ; 76.03 \pm 7.02$ vs. $93.79 \pm 11.29, \mathrm{P}=0.009$; respectively). In contrast, the si-GSK-3 $\beta$ in ES2 (HNF-1 $\beta$ negative) cells did not show differentiation neither at 48 and $72 \mathrm{~h}(101.61 \pm 4.44$ vs. $100.79 \pm 3.09 ; 98.61 \pm 6.08$ vs. $102.16 \pm 11.09$ ) (Fig. $2 \mathrm{~A})$. To confirm the interference of GSK-3 $\beta$, we further assessed the relative GSK-3 $\beta$ mRNA and protein expression levels between GSK-3 $\beta$ knockdown group and control group by RT-PCR and western blotting, respectively. As a result, GSK-3 $\beta$ knockdown group was confirmed to sufficiently suppress mRNA expression of GSK-3 $\beta$ (Fig. 2B), and protein levels of GSK-3 $\beta$ were also decreased in GSK-3 $\beta$ knockdown group compared to control group (Fig. 2C and D).

Interference of GSK-3 $\beta$ expression affects cell cycle. We assessed the effect of interference of GSK-3 $\beta$ on cell cycle and apoptosis in TOV-21G cells. Knockdown of GSK-3 $\beta$ resulted in sub-G1 phase accumulation and $\mathrm{S}$ phase reduction compared 


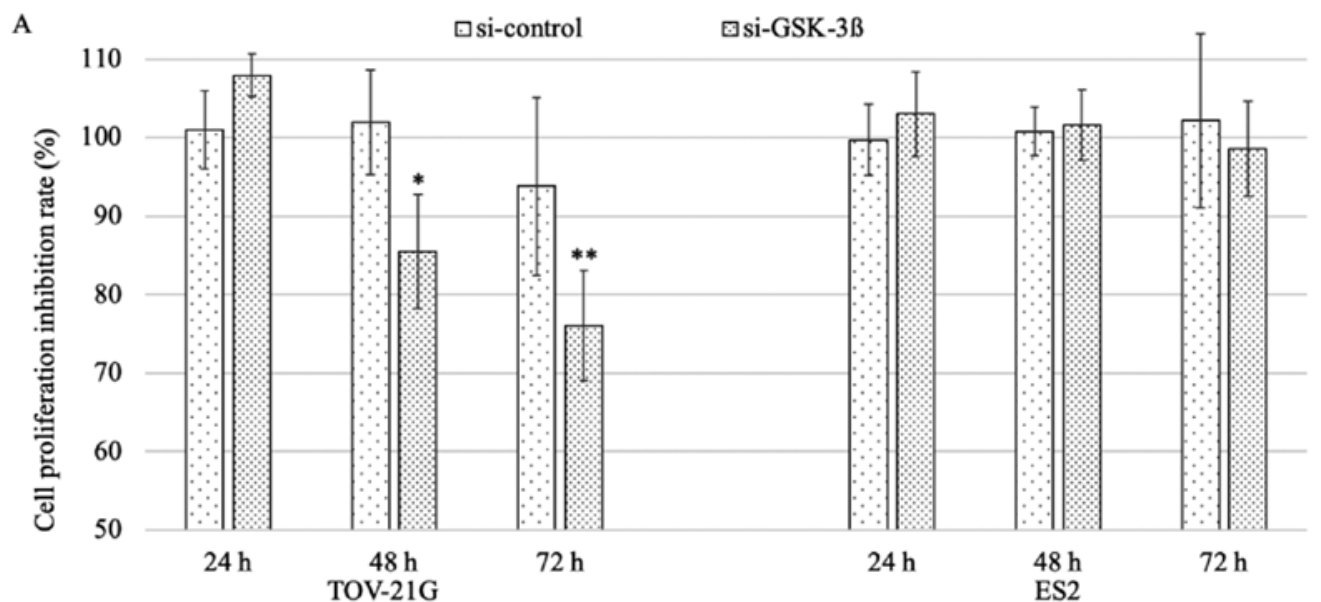

B

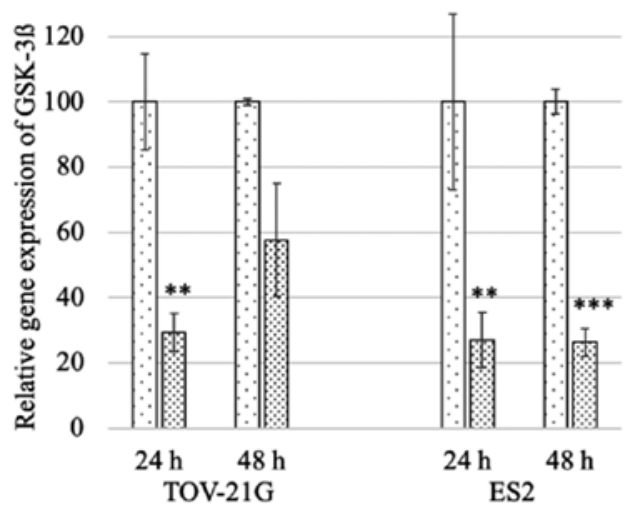

D

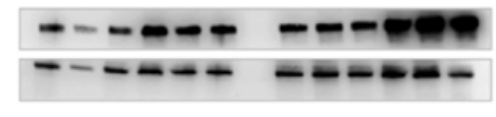

si-GSK-3B si-control si-GSK-3B si-contro

$48 \mathrm{~h}-72 \mathrm{~h}$

TOV-21G

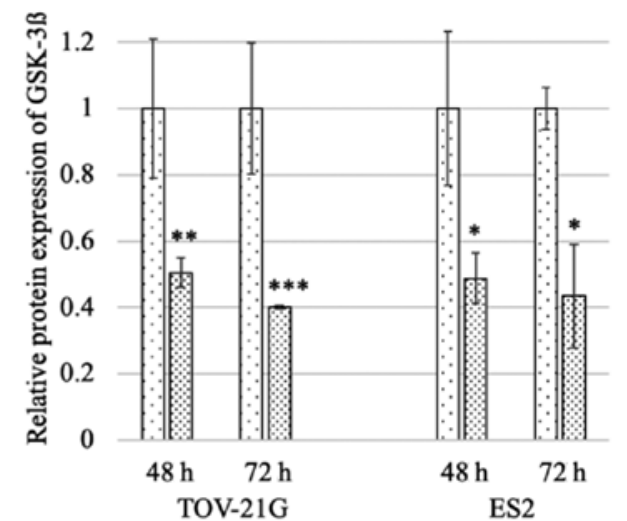

TOV-21G

Figure 2. Effect of GSK-3 $\beta$ interference on cell proliferation. (A) Cell proliferation was assessed using TOV21G (HNF-1 $\beta$ overexpressed) and ES cells (HNF-1 $\beta$ negative). The relative (B) gene and (C) protein expressions of GSK-3 $\beta$ were determined and (D) western blotting was performed. ${ }^{* * * *} \mathrm{P}<0.001,{ }^{, * *} \mathrm{P}<0.01$ and ${ }^{*} \mathrm{P}<0.05$ vs. control. GSK-3 $\beta$, glycogen synthase kinase- $3 \beta$; HNF-1 $\beta$, HNF1 homeobox $\beta$.

A

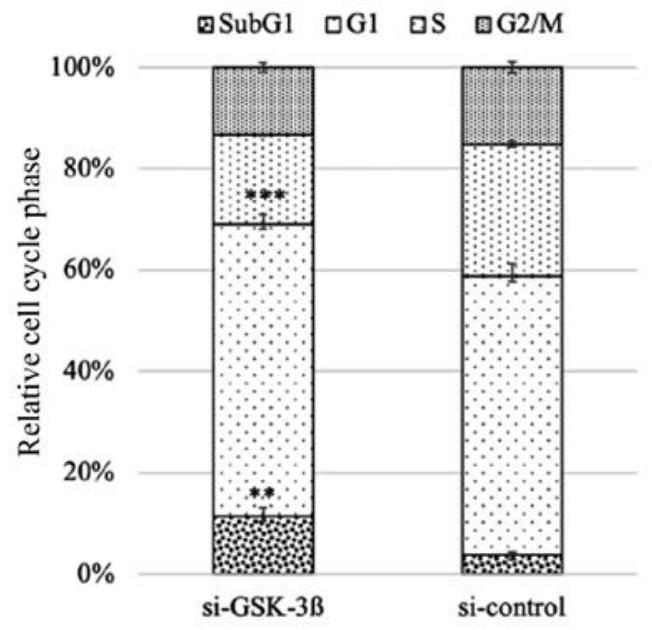

B
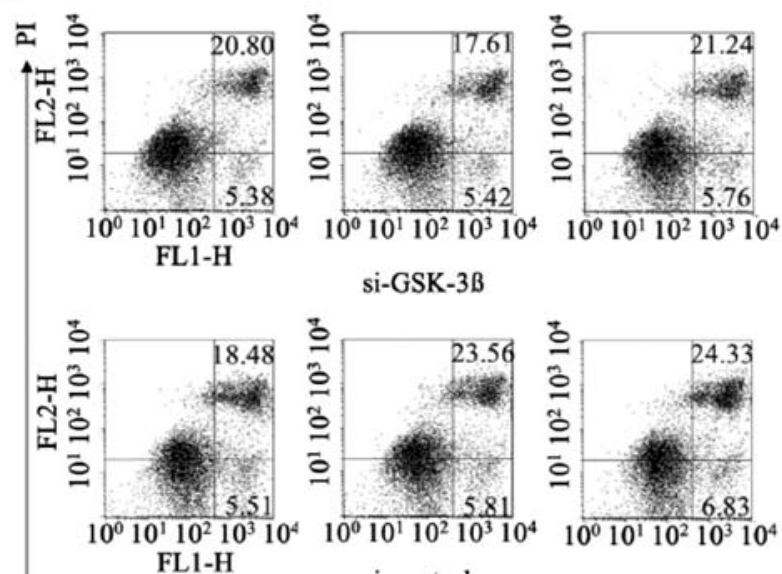

si-control

Apoptosis assay

Figure 3. Effect of GSK-3 $\beta$ interference on the cell cycle and apoptosis. The TOV-21G cell line (HNF-1 $\beta$ overexpressed) was utilized. (A) Interference of GSk-3 $\beta$ influenced Sub-G1 and S phases. (B) No significant differences were observed between the si-GSK-3 $\beta$ and control group following an apoptosis assay. ${ }^{* * * *} \mathrm{P}<0.001$ and $^{* * *} \mathrm{P}<0.01$ vs. control. GSK-3 $\beta$, glycogen synthase kinase-3 $\beta ;$ HNF-1 $\beta$, HNF1 homeobox $\beta$; si, small interfering. 


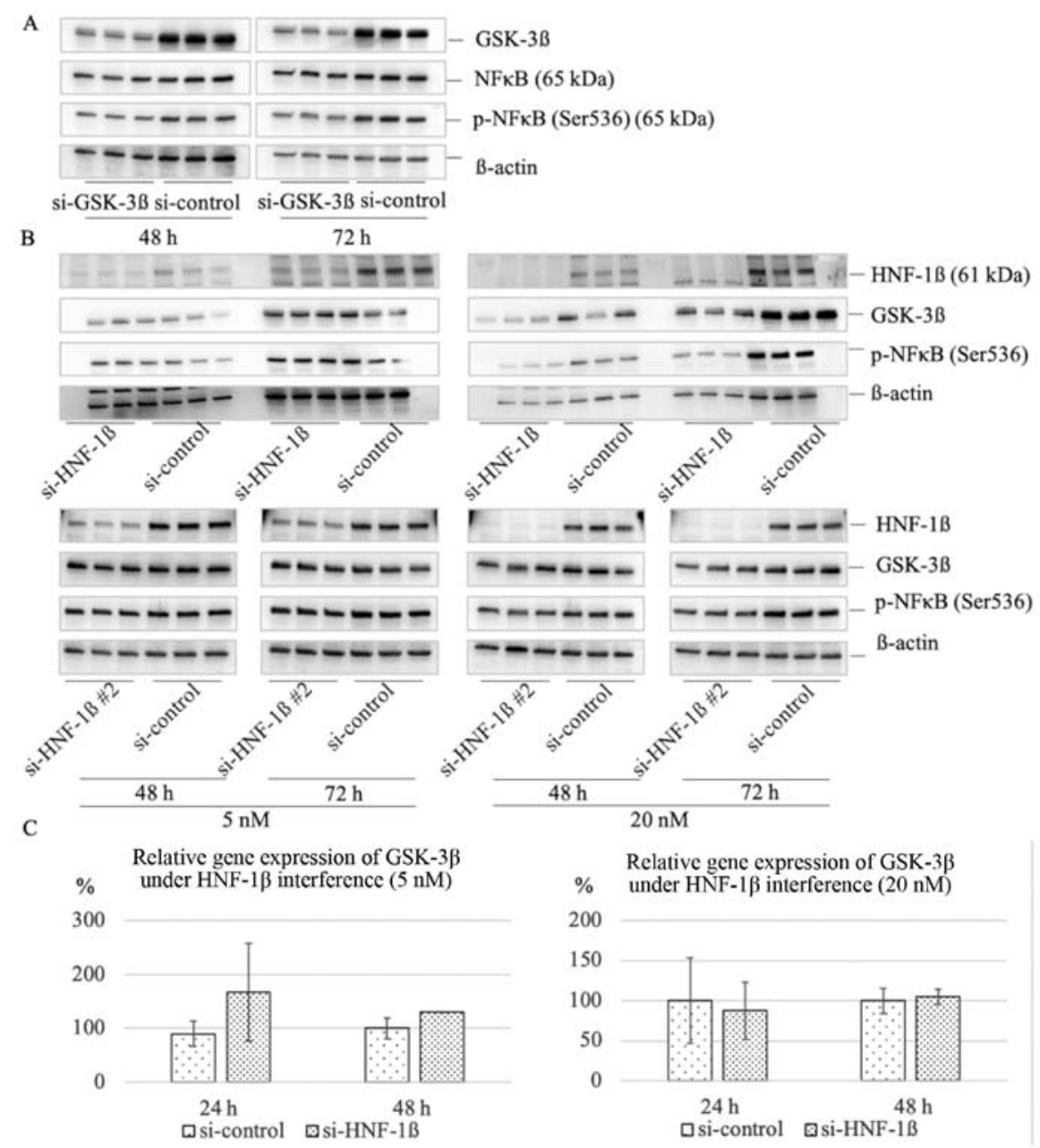

Figure 4. Effect of GSK-3 $\beta$ and HNF-1 $1 \beta$ on the protein expression of GSK-3 $\beta$ and the phosphorylation of NF- $\kappa$ B. The TOV-21G cell line (HNF-1 $\beta$ overexpressed) was utilized. (A) Interference of GSK-3 $\beta(5 \mathrm{nM})$ revealed a significant reduction of $\mathrm{p}-\mathrm{NF}-\mathrm{\kappa B}$. (B) At higher concentrations of si-HNF-1 $\beta$ and si-HNF-1 $\beta$ \#2, the expression of GSK-3 $\beta$ and p-NF- $\kappa B$ was significantly reduced. (C) Interference of HNF-1 $\beta$ did not effect GSK-3 3 mRNA expression. GSK-3 $\beta$, glycogen synthase kinase-3 $\beta$; HNF-1 $\beta$, HNF1 homeobox $\beta ;$, phosphorylated; si, small interfering.

with the control group $(10.84 \pm 1.66$ vs. $3.60 \pm 0.45, \mathrm{P}=0.002$; $16.64 \pm 0.06$ vs. $24.21 \pm 0.56, \mathrm{P}<0.001$, respectively) (Fig $3 \mathrm{~A}$ ). However, in the apoptosis assay, no significant difference was observed between the si-GSK-3 $\beta$ and control group (Fig. 3B).

$H N F-1 \beta$ regulates expression of GSK-3 $\beta$ and phosphorylation of $N F \kappa B$. Previous studies have shown that GSK-3 $\beta$ regulates serine 536 phosphorylation of NFKB subunit $(9,10)$. We confirmed effective reduction of GSK- $3 \beta$ expression at $48 \mathrm{~h}$ and $72 \mathrm{~h}(0.60 \pm 0.043$ vs. $1.00 \pm 0.11, \mathrm{P}=0.004 ; 0.43 \pm 0.068$ vs. $1.00 \pm 0.021, \mathrm{P}<0.001$, respectively). At $48 \mathrm{~h}$ after transfection of $5 \mathrm{nM}$ si-GSK-3 $\beta$, there was no significant reduction

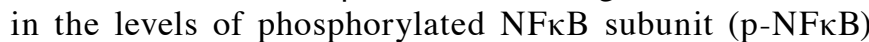
compared with the si-control group $(0.97 \pm 0.11$ vs. $1.00 \pm 0.15$, $\mathrm{P}=0.801$ ); however, at $72 \mathrm{~h}$, a significant reduction of $\mathrm{p}-\mathrm{NF \kappa B}$ ( $0.64 \pm 0.015$ vs. $1.00 \pm 0.034, \mathrm{P}<0.001)$ was observed (Fig. $4 \mathrm{~A})$. To assess whether HNF-1 $\beta$ have an effect on GSK-3 $\beta$ protein expression and phosphorylation of $\mathrm{NF \kappa B}$ subunit, we transfected 5 or $20 \mathrm{nM}$ of si-HNF-1 $\beta$ or si-HNF-1 $\beta$ \#2 into TOV-21G. At the lower concentration, si-HNF-1 $\beta$ \#2 $(5 \mathrm{nM})$ reduced phosphorylation of NFKB at $72 \mathrm{~h}(0.80 \pm 0.033$ vs. $1.00 \pm 0.019, \mathrm{P}=0.001)$. At the higher concentration of si-HNF-1 $\beta$ or si-HNF-1 $\beta$ \#2 (20nM), the expression of GSK-3 $\beta$ at $72 \mathrm{~h}$ was significantly suppressed $(0.63 \pm 0.13$ vs. $1.00 \pm 0.14$, $\mathrm{P}=0.029 ; 0.64 \pm 0.079$ vs. $1.00 \pm 0.14, \mathrm{P}=0.018$, respectively), and phosphorylation of $\mathrm{NF \kappa B}$ was significantly reduced at $48 \mathrm{~h}$ $(0.29 \pm 0.18$ vs. $1.00 \pm 0.25, \mathrm{P}=0.015 ; 0.70 \pm 0.14$ vs. $1.00 \pm 0.045$, $\mathrm{P}=0.021$, respectively) and $72 \mathrm{~h}(0.37 \pm 0.025$ vs. $1.00 \pm 0.16$, $\mathrm{P}=0.002,0.59 \pm 0.035$ vs. $1.00 \pm 0.074, \mathrm{P}=0.001$; respectively) compared with the control group (Fig. 4B). We investigated whether HNF-1 $\beta$ directly regulate GSK-3 $\beta$ messenger RNA, but HNF-1 $\beta$ does not promote production of GSK-3 $\beta$ mRNA (Fig. 4C)

$H N F-1 \beta$ plays important role on regulating GSK-3 $\beta$ activity. To investigate GSK-3 $\beta$ protein activity and stability, relative phosphorylation of GSK-3 $\beta$ (Ser 9) was assessed under lower and higher concentration of HNF-1 $\beta$ interference at 48 and $72 \mathrm{~h}$. Under lower interference of HNF-1 $\beta$, relative GSK-3 $\beta$ phosphorylation increased compared to si-control at $72 \mathrm{~h}(180.27 \pm 33.81$ vs. $100.00 \pm 32.61, \mathrm{P}=0.042)$. Under higher interference of HNF-1 $\beta$, relative GSK-3 $\beta$ phosphorylation significantly decreased compared to si-control at both times $(59.24 \pm 9.75$ vs. $100.00 \pm 5.64, \mathrm{P}=0.003 ; 69.08 \pm 4.92$ vs. $100.00 \pm 9.17, \mathrm{P}=0.049$; Fig. $5 \mathrm{~A}$ ). Furthermore, we assessed whether phosphorylated GSK-3 $\beta$ (Ser 9) distribution differ 
A
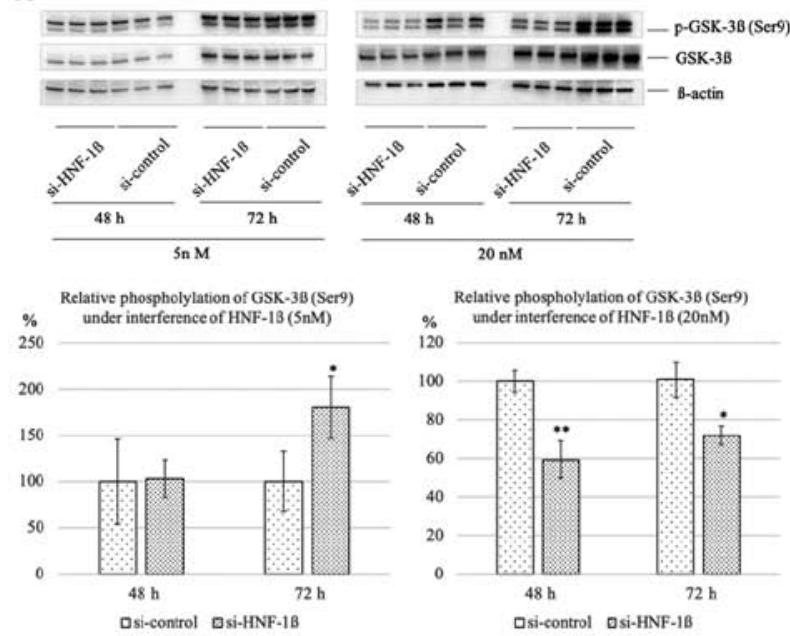
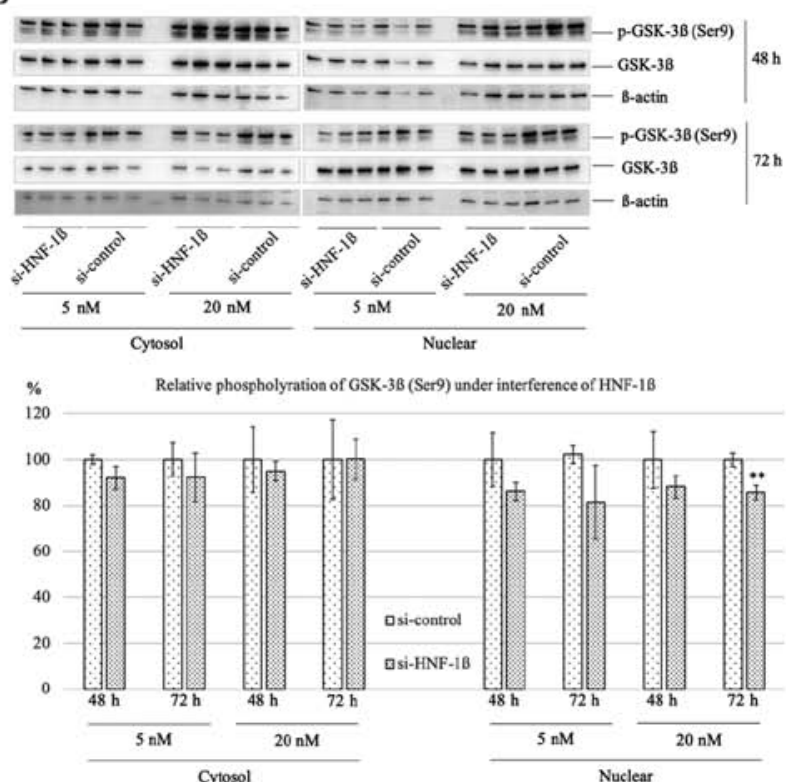

Figure 5. Effect of HNF-1 $\beta$ interference on GSK-3 $\beta$ activity. The TOV-21G cell line (HNF-1 $\beta$ overexpressed) was utilized. (A) Under higher interference of HNF-1 $\beta$, levels of phosphorylated GSK-3 $\beta$ were significantly decreased compared with the si-control. (B) Interference of HNF-1 $1 \beta$ effected GSK- $3 \beta$ nuclear activity rather than cytosolic activity. ${ }^{* *} \mathrm{P}<0.01$ and ${ }^{*} \mathrm{P}<0.05$ vs. control. HNF-1 $\beta$, HNF1 homeobox $\beta$; GSK-3 $\beta$, glycogen synthase kinase-3 $\beta$; si, small interfering.

A

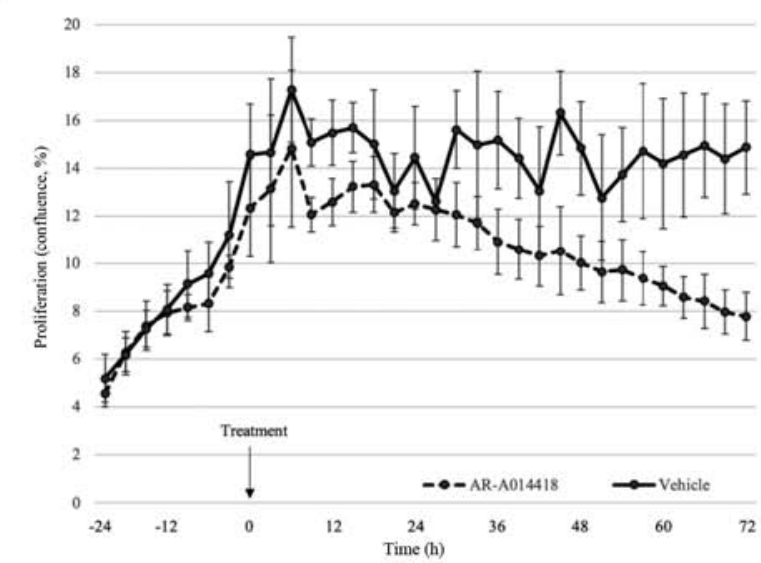

$\mathrm{C}$

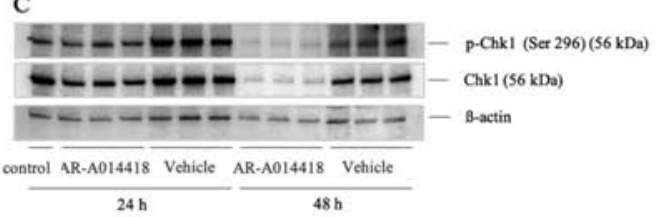

B
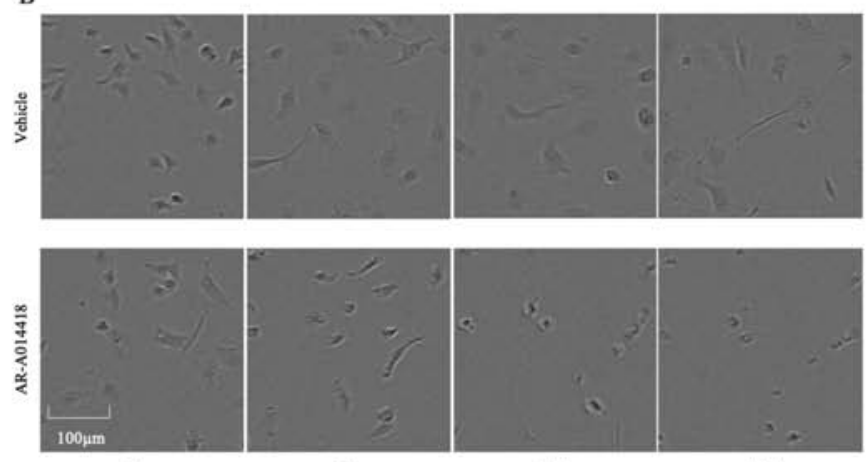

$24 \mathrm{~h}$

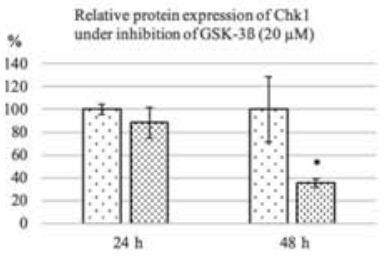

Dvehicle DAR-A01441

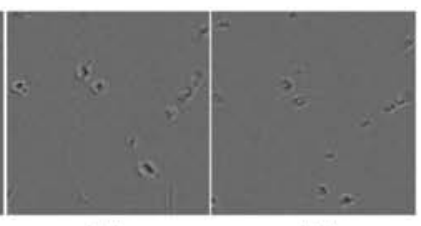

$48 \mathrm{~h}$

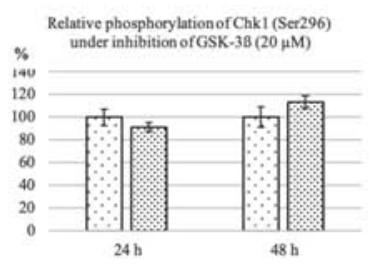

avehicle DAR-A014418

Figure 6. Effect of GSK-3 $\beta$ inhibition on cell proliferation and Chk1 stabilization. (A) TOV-21G (HNF-1 $\beta$ overexpressed) cells were treated with $42 \mu \mathrm{M}$ bleomycin and exposed to AR-A014418 or vehicle. Once confluence was reached, cells were measured every $3 \mathrm{~h}$ using IncuCyte Zoom. The solid and broken line indicates the vehicle and GSK-3 3 inhibitor, respectively. (B) TOV-21G cells treated with AR-A014418 exhibited decreased adherence and migration. (C) Chk1

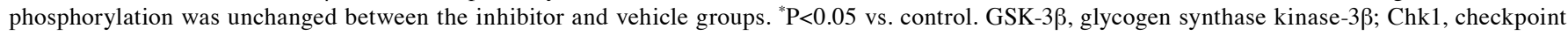
kinase 1.

in the cytosol or nuclear under lower and higher HNF-1 $\beta$ interference. There were trends to decrease relative GSK-3 $\beta$ phosphorylation in cytosol and nuclear. Especially, under higher interference of HNF-1 $\beta$ at $72 \mathrm{~h}$, significant reduction of relative GSK-3 $\beta$ phosphorylation was confirmed compared to si-control ( $85.65 \pm 3.17$ vs. $100.00 \pm 2.91, \mathrm{P}=0.004$; Fig. $5 \mathrm{~B})$.

To determine whether GSK- $3 \beta$ inhibitor AR-A014418 is cytotoxic to TOV-21G cells in vitro, cell proliferation was determined after exposure to AR-A014418 by the IncuCyte ZOOM $^{\mathrm{TM}}$ Live-Cell Imaging system. TOV-21G cells were grown in 6-well dish $\left(2.0 \times 10^{5}\right.$ cells per well) treated by $42 \mu \mathrm{M}$ bleomycin at $0 \mathrm{~h}$. The AR-A014418 or vehicle group were measured confluence (\%) every $3 \mathrm{~h}$ by IncuCyte Zoom (Fig. 6A). IncuCyte Zoom imaging suggested that TOV-21G cells treated by AR-A014418 lose its adherence or migration activity (Fig. 6B). We assessed whether GSK-3 $\beta$ act as a down- 


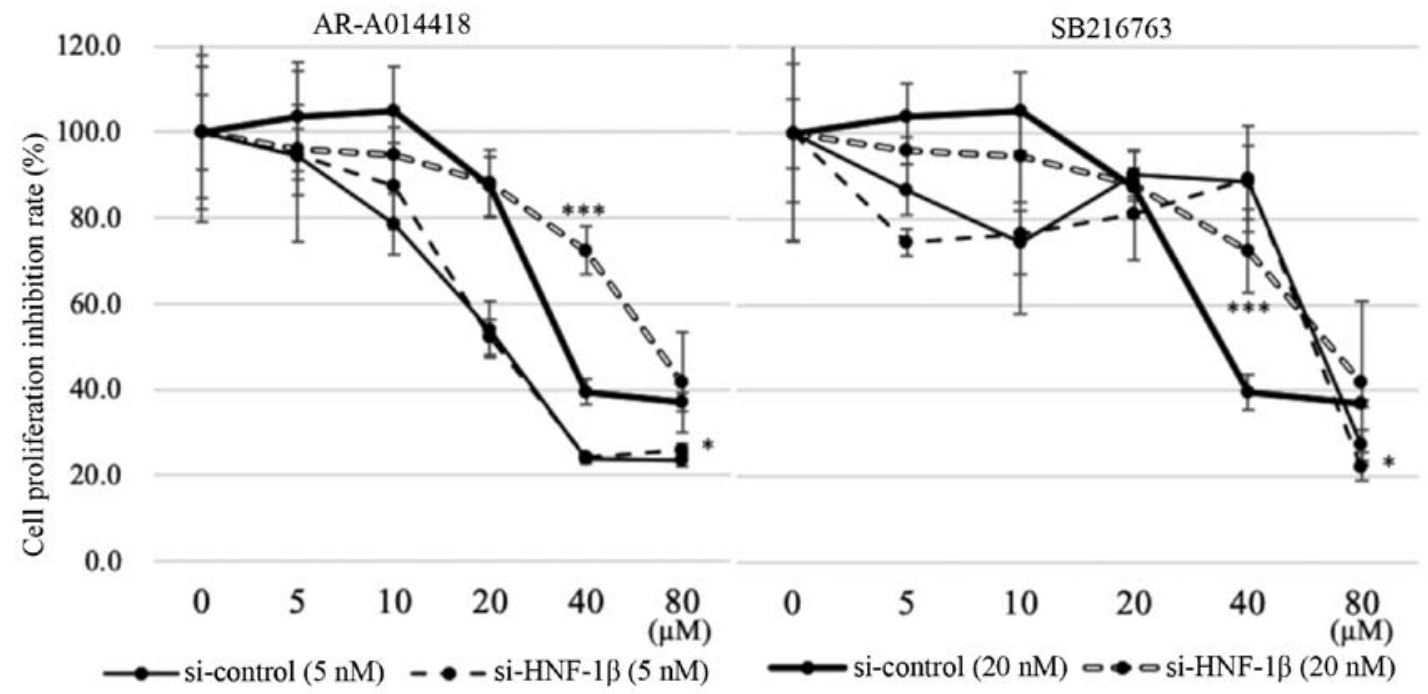

Figure 7. Interference of HNF-1 $\beta$ rescued cell proliferation. Thin and bold lines indicate lower $(5 \mathrm{nM})$ and higher $(20 \mathrm{nM})$ interference, respectively. Solid and broken lines indicate the si-control and si-HNF-1 $\beta$ group, respectively. Lower interfered cells exhibited similar cell viabilities at each inhibitor concentration. However, higher interfered cells exhibited considerable rescue of cell viability at $40 \mu \mathrm{M}$. ${ }^{* * *} \mathrm{P}<0.001$ and ${ }^{*} \mathrm{P}<0.05$ vs. control. HNF-1 $\beta$, HNF1 homeobox $\beta$; si, small interfering.

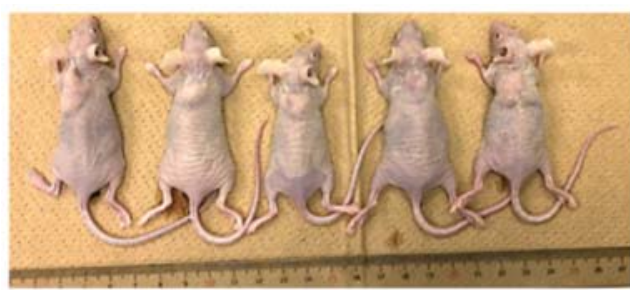

Control group

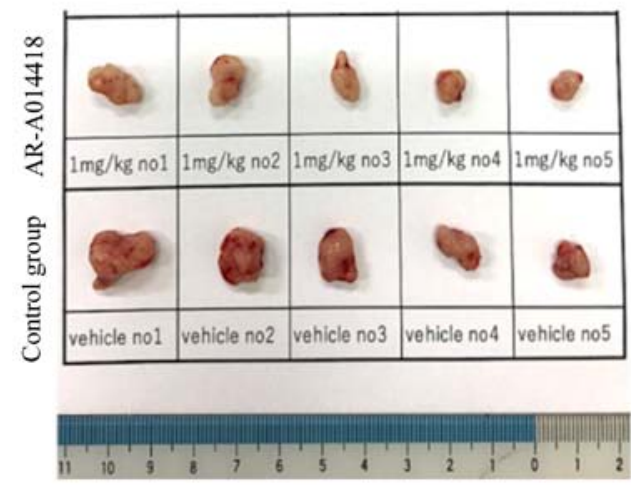

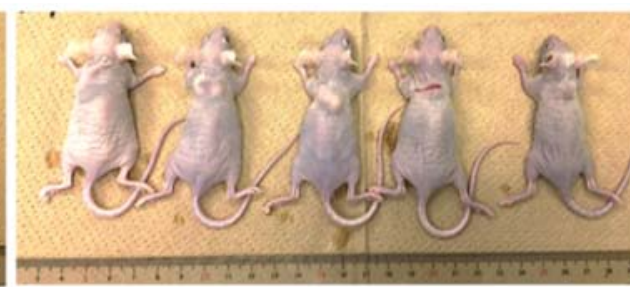

AR-A014418

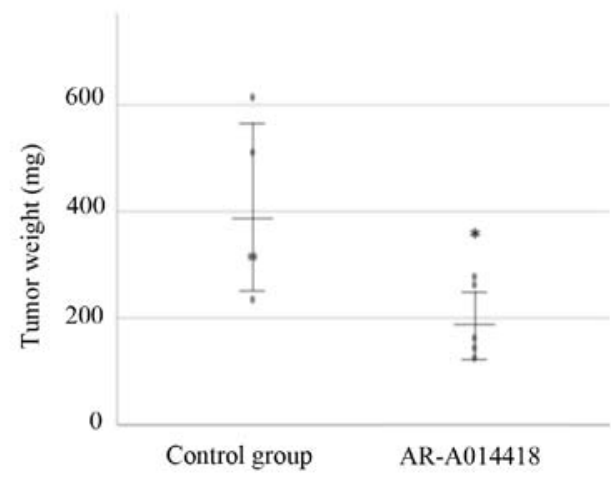

Figure 8. Effect of GSK-3 $\beta$ inhibition on tumor growth. After reaching the tumor palpable point, the inhibitor (AR-A014418) and vehicle were administered intraperitoneally for 7 days. The inhibitor group exhibited significantly decreased tumor growth compared with the control group. "P<0.05 vs. control. GSK- $3 \beta$, glycogen synthase kinase- $3 \beta$.

stream target to promote Chk1 activation as phosphorylation. Protein expression of Chk 1 and relative phosphorylation of Chk1 upon treatment of GSK-3 $\beta$ inhibitor after bleomycin stimulation were assessed. Although relative Chk1 phosphorylation showed no differentiation, protein expression of Chk1 decreased in inhibitor AR-A014418 group compared to vehicle group at 48 h (35.29 \pm 3.63 vs. $100.00 \pm 28.42, \mathrm{P}=0.017$; Fig. 6C).

$H N F-1 \beta$ expression level affects the efficacy of $G S K-3 \beta$ inhibitor. Cells were treated with two structurally distinct pharmacological inhibitors of GSK-3 $\beta$ (AR-A014418 and SB-216763) to determine whether GSK-3 $\beta$ is downstream of the HNF-1 $\beta$ signaling pathway by cell viability. Consistent with the western blotting result, lower knockdown of HNF-1 $\beta$ with a low siRNA concentration $(5 \mathrm{nM})$ did not yield a significant difference between the si-HNF-1 $\beta$ and si-control groups. However, under higher concentration (20 $\mathrm{nM}$ ), the knockdown of HNF-1 $\beta$ significantly rescued the effect of both inhibitors (applied at $40 \mu \mathrm{M})(72.43 \pm 5.69$ vs. $39.53 \pm 2.86, \mathrm{P}<0.001 ; 67.86 \pm 9.73$ vs. $30.89 \pm 4.12, \mathrm{P}<0.001$, respectively) (Fig. 7).

AR-A014418 inhibits tumor growth in xenograft mouse model. To determine whether the GSK-3 $\beta$ inhibitor shows a 
suppressive effect on tumor growth, we conducted an in vivo assay using a xenograft mouse model. To make murine subcutaneous tumors, $4.5 \times 10^{6}$ TOV-21G cells in $200 \mu 1$ of PBS were injected subcutaneously into the neck of the dorsal midline in 5- to 6-week-old athymic nude mice (SLC). After tumor palpable point, the inhibitor (AR-A014418) and vehicle were administered intraperitoneally for 7 days. At the beginning and end of administration, mice weight did not show significant differentiation between inhibitor-treated group and vehicle group $(15.99 \pm 1.30$ vs. $16.54 \pm 2.10, \mathrm{P}=0.632 ; 17.27 \pm 1.38$ vs. $16.39 \pm 1.94, \mathrm{P}=0.428$, respectively). The inhibitor-treated group showed significantly decreased tumor growth compared with the control group (194.48 \pm 70.28 vs. $398.30 \pm 157.80$, $\mathrm{P}=0.042$; Fig. 8).

\section{Discussion}

A high concentration of free iron due to repeated hemorrhage and inflammation is frequently detected in ovarian endometriotic cysts; this condition leads to carcinogenesis through iron-induced persistent oxidative stress and DNA damage (11-13). Interestingly, iron-induced reactive oxygen species (ROS) signaling promotes survival of endometriotic cell, possibly by activating the detoxification and anti-apoptotic pathways via overexpression of $\operatorname{HNF}-1 \beta(3,4,14,15)$. Given that some ROS act as a messenger in the TNF- $\alpha$ and okadaic

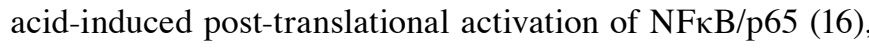
it is suggested that the persistent oxidative stress in endometriotic cysts may serve as an activator of $\mathrm{NF} \kappa \mathrm{B}$ signaling and HNF-1 $\beta$ expression.

Our previous study showed that HNF-1 $\beta$ is overexpressed in OCCC (3). This transcription factor is associated with cell survival and cell cycle arrest at the G2 phase, concomitant with accumulation of $\mathrm{p}-\mathrm{Chk} 1$, a key regulator of the cell cycle arrest after a genotoxic stress (3). We further identified an ubiquitin hydrolase, USP28, as a candidate downstream target of HNF-1 $\beta$ and as a stabilizer of Claspin protein, which is a binding partner of Chk1. Taken together, HNF-1 $\beta$ regulates Claspin protein stability and Chk1 protein activation, leading to the G2 cell cycle arrest in response to DNA damage, by controlling the USP28-dependent ubiquitin-proteasome pathway (4).

In the current study, we identified GSK-3 $\beta$ as a key gene in HNF-1 $\beta$ overexpressing OCCC. Among several candidate genes, GSK-3 $\beta$ was chosen to be a desirable target by following reasons: i) small molecular inhibitor targeted HNF-1 $\beta$ is not exist. ii) GSK-3 $\beta$ is reported not only to play an important role in cancer progression, but also associated with several neuro degenerative disease, including Parkinson's disease (5), Alzheimer's disease (17-21), Huntington's disease (22). Moreover in the several clinical trials using GSK-3 $\beta$ inhibitor targeted Alzheimer's disease, advanced solid tumors and acute myelogenous leukemia inhibitors of GSK-3 $\beta$ revealed its safety (23-25). GSK-3 $\beta$ has been previously reported to play an essential role in maintaining constitutive $\mathrm{NF} \kappa \mathrm{B}$ reporter activity and expression of $\mathrm{NF \kappa B}$ target genes in pancreatic cancer cells (10). Moreover, the two GSK-3 $\beta$ isoforms function to regulate constitutive $\mathrm{NF \kappa B}$ activity in Panc- 1 and MiaPaCa-2 cells (9). We confirmed that GSK-3 $\beta$ activates NFkB by phosphorylating it in the TOV-21G OCCC cell line. We further showed that GSK-3 $\beta$ is a downstream target of HNF-1 $\beta$ based on the following three observations: i) the effect of GSK-3 $\beta$ interference on cell proliferation was observed only in the background of HNF-1 $\beta$ overexpression. ii) Based on our western blotting analysis, HNF-1 $\beta$ could regulate both the expression of GSK-3 $\beta$ and phosphorylation of NFKB. iii) Strong silencing of HNF-1 $\beta$ increased the $\mathrm{IC}_{50}$ of two structurally distinct pharmacological inhibitors of GSK-3 $\beta$ (AR-A014418 and SB-216763). Together, these results support that GSK-3 $\beta$ is a candidate downstream target of HNF-1 $\beta$.

Previous study reported that NFאB modulates transcriptional upregulation of HNF-1 $\beta$ through alteration in bcl-2 expression (26). In the current study, the stronger silencing of HNF-1 $\beta$ resulted in a more dramatic change in the phosphorylation of $\mathrm{NF} \kappa \mathrm{B}$ rather than in the protein expression $\mathrm{NF}-\kappa \mathrm{B}$. This suggests that the role of GSK-3 $\beta$ is mainly to phosphorylate $\mathrm{NF} \kappa \mathrm{B}$ to activate downstream signaling. To our best knowledge, there are no reports regarding auto phosphorylation of $\mathrm{NF} \kappa \mathrm{B}$, suggesting that GSK-3 $\beta$ might be crucial for activation of $\mathrm{NF \kappa B}$.

Our study has some limitations. Firstly, we evaluated the effectiveness of GSK-3 $\beta$ inhibition only using two types of OCCC cell lines, namely TOV-21G (HNF-1 $\beta$ overexpression) and ES2 (HNF-1 $\beta$ negative). To validate these results and identify more specific effects on HNF-1 $\beta$ overexpression, further studies should be conducted using knocking or knockout HNF-1 $\beta$ cell lines. Secondly, because HNF-1 $\beta$ does not promote production of GSK-3 $\beta$ mRNA (Fig. 4C), there could be involvement of some kind of proteasome degradation-related protein, such as members of the USP family, as identified in our previous study. Therefore, to investigate the detailed mechanism, further screening focusing on the USP family is needed.

In conclusion, this study showed for the first time that GSK-3 $\beta$ is a target gene of HNF-1 $\beta$. In addition, our findings reveal the novel pathway of HNF-1 $\beta-$ GSK-3 $\beta-\mathrm{p}-\mathrm{NF} \kappa \mathrm{B}$ axis in response to DNA damage. Targeting this pathway may represent a putative, novel, anticancer strategy in OCCC.

\section{Acknowledgements}

Not applicable.

\section{Funding}

The current study was supported by JSPS KAKENHI (grant no. JP16K11150) and the Kanzawa Medical Research Foundation (grant no. 30-28).

\section{Availability of data and materials}

All data generated or analyzed during the present study are included in this published article.

\section{Authors' contribution}

NK and HK deigned the current study. NK and AM collected data from PubMed and performed the experiments. AM, $\mathrm{SM}$ and YT conducted in vivo experiments. NK wrote and 
proofread the manuscript. All authors read and approved the manuscript

\section{Ethics approval and consent to participate}

The present study was approved by the Animal Ethics Committee of Nara Medical University (reference no. 12594).

\section{Patient consent for publication}

Not applicable.

\section{Competing interests}

The authors declare that they have no competing interests.

\section{References}

1. Ferlay J, Soerjomataram I, Ervik M, Dikshit R, Eser S, Mathers C Rebelo M,Parkin DM, Forman D and Bray F (eds): GLOBOCAN 2012: Estimated Cancer Incidence, Mortality and Prevalence Worldwide in 2012. IARC CancerBase No. 11. International Agency for Research on Cancer, Lyon, 2013.

2. Tsuchiya A, Sakamoto M, Yasuda J, Chuma M, Ohta T, Ohki M, Yasugi T, Taketani Y and Hirohashi S: Expression profiling in ovarian clear cell carcinoma: Identification of hepatocyte nuclear factor-1 beta as a molecular marker and a possible molecular target for therapy of ovarian clear cell carcinoma. Am J Pathol 163: 2503-2512, 2003.

3. Shigetomi H, Sudo T, Shimada K, Uekuri C, Tsuji Y, Kanayama S, Naruse K, Yamada Y, Konishi N and Kobayashi H: Inhibition of cell death and induction of G2 arrest accumulation in human ovarian clear cells by HNF-1 $\beta$ transcription factor: Chemosensitivity is regulated by checkpoint kinase CHK1. Int J Gynecol Cancer 24: 838-843, 2014.

4. Ito F, Yoshimoto C, Yamada Y, Sudo T and Kobayashi H: The HNF-1 $\beta$-USP28-Claspin pathway upregulates DNA damage-induced Chk1 activation in ovarian clear cell carcinoma. Oncotarget 9: 17512-17522, 2018.

5. Senkel S, Lucas B, Klein-Hitpass L and Ryffel GU: Identification of target genes of the transcription factor HNF1beta and HNF1alpha in a human embryonic kidney cell line. Biochim Biophys Acta 1731: 179-190, 2005.

6. Tanaka T, Tomaru Y, Nomura Y, Miura H, Suzuki M and Hayashizaki Y: Comprehensive search for HNF-1beta-regulated genes in mouse hepatoma cells perturbed by transcription regulatory factor-targeted RNAi. Nucleic Acids Res 32: 2740-2750, 2004.

7. Livak KJ and Schmittgen TD: Analysis of relative gene expression data using real time quantitative PCR and the 2 (Delta Delta C(T)) method. Methods 25: 402 408, 2001.

8. Johnston ST, Shah ET, Chopin LK, Sean McElwain DL and Simpson MJ: Estimating cell diffusivity and cell proliferation rate by interpreting IncuCyte $\mathrm{ZOOM}^{\mathrm{TM}}$ assay data using the Fisher-Kolmogorov model. BMC Syst Biol 9: 38, 2015.

9. Wilson W III and Baldwin AS: Maintenance of constitutive IkappaB kinase activity by glycogen synthase kinase- $3 \alpha / \beta$ in pancreatic cancer. Cancer Res 68: 8156-8163, 2008.

10. Ougolkov AV, Fernandez-Zapico ME, Savoy DN, Urrutia RA and Billadeau DD: Glycogen synthase kinase-3beta participates in nuclear factor kappaB-mediated gene transcription and cell survival in pancreatic cancer cells. Cancer Res 65: 2076-2081, 2005.

11. Kajihara H, Yamada Y, Kanayama S, Furukawa N, Noguchi T, Haruta S, Yoshida S, Sado T, Oi H and Kobayashi H: Clear cell carcinoma of the ovary: Potential pathogenic mechanisms (Review). Oncol Rep 23: 1193-1203, 2010.
12. Yamaguchi K, Mandai M, Toyokuni S, Hamanishi J, Higuchi T, Takakura K and Fujii S: Contents of endometriotic cysts, especially the high concentration of free iron, are a possible cause of carcinogenesis in the cysts through the iron-induced persistent oxidative stress. Clin Cancer Res 14: 32-40, 2008.

13. Niiro E, Kawahara N, Yamada Y, Yoshimoto C, Shimada K, Sudo $\mathrm{T}$ and Kobayashi H: Immunohistochemical expression of CD44v9 and 8-OHdG in ovarian endometrioma and the benign endometriotic lesions adjacent to clear cell carcinoma. J Obstet Gynaecol Res 45: 2260-2266; Epub ahead of print, 2019.

14. Yamada Y, Shigetomi H, Onogi A, Haruta S, Kawaguchi R, Yoshida S, Furukawa N, Nagai A, Tanase Y, Tsunemi T, et al: Redox-active iron-induced oxidative stress in the pathogenesis of clear cell carcinoma of the ovary. Int J Gynecol Cancer 21: 1200-1207, 2011.

15. Shigetomi $H$, Higashiura $Y$, Kajihara $H$ and Kobayashi $H$ : A potential link of oxidative stress and cell cycle regulation for development of endometriosis. Gynecol Endocrinol 28: 897-902, 2012.

16. Schmidt KN, Amstad P, Cerutti P and Baeuerle PA: The roles of hydrogen peroxide and superoxide as messengers in the activation of transcription factor NF- $\kappa$ B. Chem Biol 2: 13-22, 1995.

17. Zhang Y, Huang N, Yan F, Jin H, Zhou S, Shi J and Jin F: Diabetes mellitus and Alzheimer's disease: GSK-3 $\beta$ as a potential link. Behav Brain Res 339: 57-65, 2018.

18. Llorens-Martín M, Jurado J, Hernández F and Avila J: GSK-3 $\beta$, a pivotal kinase in Alzheimer disease. Front Mol Neurosci 7: 46, 2014.

19. Llorens-Martín M, Blazquez-Llorca L, Benavides-Piccione R, Rabano A, Hernandez F, Avila J and DeFelipe J: Selective alterations of neurons and circuits related to early memory loss in Alzheimer's disease. Front Neuroanat 8: 38, 2014.

20. Llorens-Martín M, Fuster-Matanzo A, Teixeira CM, Jurado-Arjona J, Ulloa F, Defelipe J, Rábano A, Hernández F, Soriano E and Avila J: Alzheimer disease-like cellular phenotype of newborn granule neurons can be reversed in GSK-3 $\beta$-overexpressing mice. Mol Psychiatry 18: 395-95, 2013.

21. Llorens-Martín M, Fuster-Matanzo A, Teixeira CM, Jurado-Arjona J, Ulloa F, Defelipe J, Rábano A, Hernández F, Soriano E and Avila J: GSK-3 $\beta$ overexpression causes reversible alterations on postsynaptic densities and dendritic morphology of hippocampal granule neurons in vivo. Mol Psychiatry 18: 451-460, 2013.

22. Lim NK, Hung LW, Pang TY, Mclean CA, Liddell JR, Hilton JB, Li QX, White AR, Hannan AJ and Crouch PJ: Localized changes to glycogen synthase kinase-3 and collapsin response mediator protein-2 in the Huntington's disease affected brain. Hum Mol Genet 23: 4051-4063, 2014

23. Gray JE, Infante JR, Brail LH, Simon GR, Cooksey JF, Jones SF, Farrington DL, Yeo A, Jackson KA, Chow KH, et al: A first-in-human phase I dose-escalation, pharmacokinetic, and pharmacodynamic evaluation of intravenous LY2090314, a glycogen synthase kinase 3 inhibitor, administered in combination with pemetrexed and carboplatin. Invest New Drugs 33: 1187-1196, 2015

24. Rizzieri DA, Cooley S, Odenike O, Moonan L, Chow KH Jackson K, Wang X, Brail L and Borthakur G: An open-label phase 2 study of glycogen synthase kinase-3 inhibitor LY2090314 in patients with acute leukemia. Leuk Lymphoma 57: 1800-1806, 2016.

25. Wang Z, Smith KS, Murphy M, Piloto O, Somervaille TC and Cleary ML: Glycogen synthase kinase 3 in MLL leukaemia maintenance and targeted therapy. Nature 455: 1205-1209, 2008.

26. Suzuki E, Kajita S, Takahashi H, Matsumoto T, Tsuruta T and Saegusa M: Transcriptional upregulation of HNF-1 $\beta$ by NF- $\kappa B$ in ovarian clear cell carcinoma modulates susceptibility to apoptosis through alteration in bcl-2 expression. Lab Invest 95: 962-972, 2015.

This work is licensed under a Creative Commons Attribution-NonCommercial-NoDerivatives 4.0 International (CC BY-NC-ND 4.0) License. 